\title{
FATAL NEONATAL POLIOMYELITIS
}

\author{
BY \\ R. C. B. PUGH and J. A. DUDGEON \\ From The Hospital for Sick Children, Great Ormond Street, London
}

(RECEIVED FOR PUBLICATION MAY 19, 1954)

During the present century one of the more noticeable changes in the character of poliomyelitis throughout the world has been a tendency for 'infantile paralysis' to become less common. This has been accompanied by a correspondingly greater incidence of infection in older children, and at the same time by an increase in the epidemicity and severity of the disease as a whole. Nevertheless, despite this general trend, during the years 1947-1951 inclusive, 1,147 cases of poliomyelitis in infants (aged 0-12 months) were notified in this country out of a total of 29,656 cases occurring in all age groups. A further analysis of the RegistrarGeneral's figures for these years emphasizes the seriousness of the disease at this age, as 135 of the affected infants died ( 55 were under 6 months and 23 were under 3 months of age). In 1950, which was an epidemic year, there was a significantly higher incidence of paralytic disease in children under 3 months of age than in the remainder of the group (Logan, 1952).

Before 1948 published reports of poliomyelitis occurring in infants under the age of 6 months were few and were even rarer for the neonatal period (0-28 days). However, a recent review by SimsRoberts and Thomson (1953) shows that an appreciable number of cases of poliomyelitis, many of them fatal, have been reported in young infants since 1947.

The case reported here is of an infant who died of poliomyelitis at the age of 18 days while in hospital under treatment for ectopia vesicae.

\section{Case Report}

G.W., a first born male infant, was delivered normally after a pregnancy complicated by maternal toxaemia, and was found to have ectopia vesicae and complete epispadias. He was transferred to The Hospital for Sick Children, Great Ormond Street, five hours after birth and on the second day of life surgical repair of the ectopia vesicae was undertaken. The bladder was inverted and the lower anterior abdominal wall was reconstituted over it. The immediate post-operative period was uncomplicated but the wound started to break down on the sixth post-operative day, and by the eleventh day after operation it had completely broken down so that the appearances of the lower abdomen now resembled those before the repair had been undertaken. These local changes were not accompanied by any constitutional reaction, and the only abnormal feature was a transient rise of temperature to $100^{\circ} \mathrm{F}$. on the fourth day after operation (aged 6 days). When the baby was 16 days old breast feeding was begun but the child was sleepy and reluctant to take the breast. The following day flaccidity of the lower limbs was noted and later this extended rapidly to affect the arms as well; his colour was greyish and there was occasional twitching of the facial muscles. The blood urea was $23 \mathrm{mg}$. \%. His condition gradually deteriorated throughout the day and he died the following morning (eighteenth day of life), approximately 36 hours after the onset of paralysis. The cause of death was not known, but the suggested clinical diagnoses included septicaemia, cerebral haemorrhage and adrenal haemorrhage; the possibility of poliomyelitis had been considered, but the age of the child was thought to vitiate this diagnosis.

\section{Post-mortem Appearances}

The necropsy was performed 22 hours after death. The body was that of a male infant, 21 in. in height and weighing $7 \mathrm{lb}$. The nutritional state was good and there was slight pitting oedema of the feet and legs. An oval skin deficiency was seen in the lower abdomen and there was an ectopic bladder with complete epispadias; the margins of the skin defect showed minor superficial sepsis.

The brain weighed $472 \mathrm{~g}$. (average normal for the age $382 \mathrm{~g}$.) and the parenchyma was oedematous, with poor differentiation between the grey and white matter and irregular punctate congestion in the region of both basal ganglia. Only the cervical portion of the spinal cord was examined and this revealed congestion of the grey matter. The right side of the heart was dilated and the myocardium of both ventricles was flabbier than usual, but otherwise appeared normal. The liver was fatty although its weight was within normal limits. Both lungs were oedematous and congested, but there was no evidence of consolidation. The remaining viscera 
showed the changes of passive venous congestion.

\section{Laboratory Investigations}

In view of the history of paralysis a piece of the cervical cord was excised at necropsy and preserved at $-20^{\circ} \mathrm{C}$. Later an emulsion prepared from this tissue was inoculated intracerebrally into a rhesus monkey. On the third day after inoculation fine tremors of the ears, severe ataxia and paresis of the right arm were noted. The following day the temperature had risen to $105^{\circ} \mathrm{F}$. By the seventh day paralysis of the legs and arms was evident and the animal was killed on the eighth day after inoculation. The brain and spinal cord were removed for histological examination.

\section{Histology}

Examination of the tissues from the child revealed the characteristic changes of acute poliomyelitis (Fig. 1). The individual lesions consisted of a variable meningeal reaction (lymphocytes, mononuclears and, occasionally, polymorphs in the subarachnoid space), partial or complete destruction of ganglion cells with neuronophagia, vascular congestion and perivascular cuffing with lymphocytes and polymorphs. There were also intraparenchymal collections of microglial cells and

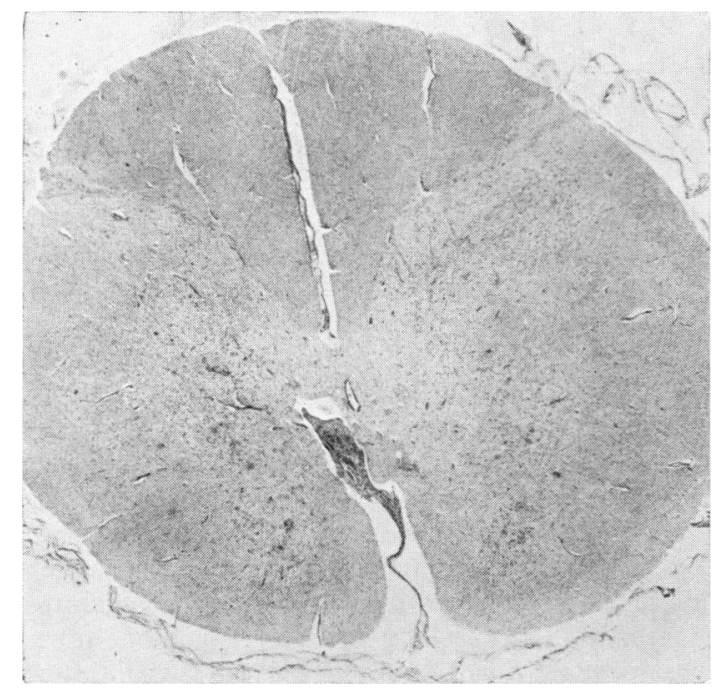

FIG. 1.-Cervical spinal cord: lesions are present in the grey matter of all the horns, but are maximal in the anterior horns. There is a well developed meningeal reaction. Haematoxylin and eosin $\times 16$.

polymorphs as well as numerous small recent haemorrhages (Fig. 2). The lesions were in the grey matter of the spinal cord (affecting all horns, but maximal in the anterior); the medulla (affecting all nuclei, but minimal in the olives); the dorsal nuclei of the pons; the roof nuclei and superior vermis of the cerebellum; and the hypothalamus. There was some swelling of the ganglion cells in the pre-central gyrus.

In the heart there were several microscopic foci of degeneration of the muscle fibres in the left ventricular wall, associated with a local infiltration with large, irregularly shaped mononuclear cells together with an occasional polymorph and lymphocyte. The muscle fibres were fragmented, and often appeared granular and more eosinophilic than usual; they had frequently lost their striations and many of the sarcolemmal nuclei were pyknotic. Occasionally the adjacent interstitial tissues were oedematous and contained large mononuclear cells.

Examination of the remaining viscera confirmed the macroscopic changes that had been noted.

The lesions in the brain and spinal cord of the monkey were essentially similar in nature and distribution to those seen in the child, except that fully developed changes were seen in the pre-central gyrus. In general, lymphocytes outnumbered polymorphs in the subarachnoid space and in the parenchyma. 


\section{Discussion}

Although the naked-eye appearances of the brain and spinal cord of the infant were not so striking as to suggest immediately the diagnosis of poliomyelitis, the clinical history of sudden flaccidity of the limbs was considered sufficient to justify the preservation of a piece of the spinal cord with a view to subsequent inoculation. As the microscopical appearance in both baby and monkey corresponded to the histological pattern which has been considered diagnostic of poliomyelitis (Luhan, 1946; Howe, 1948; Bodian, 1949), there can be no doubt that the child suffered from this disease.

Some difficulty is encountered when an attempt is made to decide the means by which this baby became infected. But the three possible alternatives that present themselves are that the child was infected in utero, at birth (as, for example, by faecal contamination from the mother) or after birth. The fact that the mother was well during the pregnancy and puerperium, apart from a mild toxaemia, would make the first two modes of infection less likely, unless it is assumed that she suffered from a sub-clinical form of the disease.
However, on the available evidence, and bearing in mind that the baby died at the age of 18 days and that the usually accepted incubation period is in the region of 10 days, it seems more likely that the infection in this case was post-natal. This belief is to some extent strengthened when it is recalled that the infant's temperature showed a transient elevation on the sixth day of life, 11 days before the paralysis was noted. It has not been possible to trace the source of the infection, although extensive enquiry was made. There were no other children in the hospital at the material time in whom a diagnosis of poliomyelitis was made; nor was there any history of the disease amongst visitors to the ward so far as is known, although clearly this only excludes those contacts with clinical disease. This apparently isolated incidence of a severe or even fatal form of the disease is not unknown in epidemiological experience and has been recorded recently in another case from this hospital (Pugh, 1952).

The Table summarizes the more important features of some of the recently reported cases of neonatal poliomyelitis and it is clear from this that only in some instances were the infants

TABLE 1

SUMMARY OF SOME CASES OF NEONATAL POLIOMYELITIS REPORTED SINCE 1947

\begin{tabular}{|c|c|c|c|c|c|c|c|}
\hline Authors & $\begin{array}{l}\text { Place and } \\
\text { Date of } \\
\text { Infection }\end{array}$ & $\begin{array}{l}\text { No. } \\
\text { of } \\
\text { Cases }\end{array}$ & $\begin{array}{l}\text { Age at } \\
\text { Onset } \\
\text { in Days }\end{array}$ & $\begin{array}{l}\text { Place } \\
\text { of } \\
\text { Birth }\end{array}$ & History of Contact & $\begin{array}{l}\text { Clinical Details } \\
\text { of Infant }\end{array}$ & $\begin{array}{l}\text { Pathological } \\
\text { Details in } \\
\text { Infant }\end{array}$ \\
\hline $\begin{array}{l}\text { 1. Mouton et al. } \\
\text { (1950) }\end{array}$ & U.S.A. & $5^{*}$ & $\begin{array}{c}14,18,{ }^{18} \\
21,21\end{array}$ & $\begin{array}{c}\text { No } \\
\text { comment }\end{array}$ & $\begin{array}{l}1 \text { case: mother had } \\
\text { paralytic polio. } \\
1 \text { case: sibling had } \\
\text { paralytic polio }\end{array}$ & $\begin{array}{l}\text { Paralysis of one limb } \\
\text { or more. No deaths }\end{array}$ & $\begin{array}{l}\text { Typical C.S.F. find- } \\
\text { ings }\end{array}$ \\
\hline $\begin{array}{l}\text { 2. Baskin et al. } \\
(1950)\end{array}$ & U.S.A. & 2 & $\begin{array}{l}4 \\
8\end{array}$ & $\begin{array}{l}\text { Hospital } \\
\text { Hospital }\end{array}$ & $\begin{array}{l}\text { Mother had paralytic } \\
\text { polio at delivery } \\
\text { Mother developed para- } \\
\text { lytic polio } 2 \text { days after } \\
\text { delivery }\end{array}$ & $\begin{array}{l}\text { Died aged } 7 \text { days } \\
\text { Died aged } 14 \text { days }\end{array}$ & $\begin{array}{l}\text { Typical lesions in } \\
\text { C.N.S. } \\
\text { Typical lesions in } \\
\text { C.N.S. Acute focal } \\
\text { myocarditis }\end{array}$ \\
\hline $\begin{array}{l}\text { 3. Smallpeice and } \\
\text { Ounsted (1952) }\end{array}$ & $\begin{array}{l}\text { U.K. } \\
1947\end{array}$ & $2 \dagger$ & 21 & $\begin{array}{l}3 \text { cases all } \\
\text { in same } \\
\text { nursing } \\
\text { home }\end{array}$ & $\begin{array}{l}\text { No contact with known } \\
\text { case of polio. } \\
\text { Same nurse delivered } \\
\text { all cases }\end{array}$ & $\begin{array}{l}\text { Died aged } 9 \frac{1}{2} \text { weeks } \\
\text { Remained paralysed } \\
\text { and mentally defective }\end{array}$ & No necropsy \\
\hline 4. Johns (1948) & $\begin{array}{l}\text { U.K. } \\
1947\end{array}$ & 1 & 4 & Home & 2 siblings had polio & Paralysed & \\
\hline $\begin{array}{l}\text { 5. McConnell } \\
\text { (1952) }\end{array}$ & $\begin{array}{l}\text { U.K. } \\
1950\end{array}$ & $1 \ddagger$ & 16 & Home & No comment & Died aged 25 days & $\begin{array}{l}\text { Typical lesions in } \\
\text { C.N.S. Acute focal } \\
\text { myocarditis }\end{array}$ \\
\hline $\begin{array}{l}\text { 6. Wright and } \\
\text { Owen (1952) }\end{array}$ & $\underset{1950}{\text { U.K. }}$ & 1 & 8 & Hospital & $\begin{array}{l}\text { Mother developed para- } \\
\text { lytic polio day before } \\
\text { delivery. Mother died }\end{array}$ & Died aged 10 days & $\begin{array}{l}\text { Typical lesions in } \\
\text { C.N.S. Acute focal } \\
\text { myocarditis }\end{array}$ \\
\hline $\begin{array}{l}\text { 7. Sims-Roberts } \\
\text { and Thomson } \\
(1953)\end{array}$ & $\begin{array}{l}\text { U.K. } \\
1952\end{array}$ & 4 & $13, \frac{12,10}{18}$ & $\begin{array}{c}\text { Same } \\
\text { hospital }\end{array}$ & No obvious contact & $\begin{array}{l}3 \text { died aged } 16,14, \\
11 \text { days. } 1 \text { paralysed }\end{array}$ & $\begin{array}{l}\text { Type III virus isolated } \\
\text { from } 2 \text { cases and } \\
\text { mother }\end{array}$ \\
\hline 8. Present case & $\begin{array}{l}\text { U.K. } \\
1953\end{array}$ & 1 & 16 & Home & $\begin{array}{l}\text { Admitted to hospital } \\
\text { for operation on day of } \\
\text { birth }\end{array}$ & Died aged 18 days & $\begin{array}{l}\text { Typical lesions in } \\
\text { C.N.S. Polio virus } \\
\text { isolated from C.N.S. } \\
\text { Focal myocarditis }\end{array}$ \\
\hline
\end{tabular}

* 5 additional cases reported under 6 months

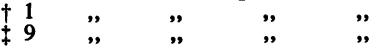


possibly infected in utero (Johns, 1948; Baskin, Soule and Mills, 1950; Wright and Owen, 1952), although Sims-Roberts and Thomson (1953) regard this as unlikely: the problem is still not resolved. In the remaining cases, although the mode of infection is not obvious, the age at which the disease became manifest suggests that a post-natal infection was more likely. In these cases it is also highly significant that the affected babies were in the same hospital (Sims-Roberts and Thomson, 1953), or nursing home (Smallpeice and Ounsted, 1952), or came from families in which contact with poliomyelitis had been established.

The factors that determine the incidence of poliomyelitis in the first six months of life are undoubtedly complex but it seems probable that maternal antibody plays some part in protecting infants at this critical time. It might be expected that after exposure to infection the mother would develop antibody and, by transplacental transmission, protect her newborn infant provided that enough time had elapsed for the antibody to have reached a titre sufficient to afford protection. That this is not always the case is probably explained by the identification of several strains of poliomyelitis virus. Each strain has a specific antibody, so that a child born to a mother exposed to infection with one or other virus strain would have incomplete antibody protection and therefore would be theoretically at risk from birth.

The occurrence of visceral lesions in poliomyelitis is well known and, although it has been suspected for a long time that they resulted from dissemination of virus through the blood stream, the presence of a viraemia in the human subject has only recently been established (Horstmann, 1953). Myocarditis has attracted particular attention among both clinicians and pathologists, and the degree of involvement of the heart varies considerably from case to case. In the case described here the changes were not obvious macroscopically but consisted of microscopic focal lesions which could easily be overlooked unless they were sought for; in a case previously reported from this hospital the changes were gross and there was widespread destruction of heart muscle (Pugh, 1952). This previous paper summarized a number of the features from the reports in the literature, and it is interesting that most authors considered that older patients were more liable to develop myocarditis than younger ones. The incidence of myocarditis varied considerably in the reported series; six out of seven cases (Saphir and Wile, 1942), two out of 12 cases (Dublin and Larson, 1943), 10 out of 17 cases (Saphir, 1945) and 14 out of 35 cases (Ludden and Edwards, 1949). In the 17 cases reviewed in this paper myocarditis was present in four out of the eight fatal cases that came to necropsy (Table 1).

The diagnosis of paralysis in the neonate is often a difficult problem and in this child poliomyelitis was not seriously considered because of the early age at which symptoms developed. But epidemiological evidence and a study of the age of onset in the cases recorded in the literature show that paralytic poliomyelitis within the first six months of life is not as rare as has hitherto been thought, so that it should be included in the differential diagnosis.

\section{Summary}

A fatal case of acute poliomyelitis in a newborn infant under treatment for ectopia vesicae and epispadias is described. The infection was successfully transmitted to a rhesus monkey. The possible mode of infection and the occurrence of visceral lesions in poliomyelitis are discussed.

Our thanks are due to Mr. D. Innes Williams and Dr. Martin Bodian for permission to publish this case.

\section{REFERENCES}

Baskin, J. L., Soule, E. H. and Mills, S. D. (1950). Amer. J. Dis. Child., 80, 10.

Bodian, D. (1949). "Poliomyelitis: Papers and Discussions presented at the First International Poliomyelitis Conference," p. 62. Philadelphia.

Dublin, W. B. and Larson, C. P. (1943). Amer. J. clin. Path., 13, 15. Horstmann, D. M. (1953). Lancet, 2, 90.

Howe, H. A. (1948). In Viral and Rickettsial Infections of Man, ed. Rivers, T. M., p. 245. Philadelphia.

Johns, A. W. (1948). Med. Offr., 80, 230.

Logan, W. P. D. (1952). Monthly Bull. Minist. Hlth, Lond., 11, 147.

Ludden, T. E. and Edwards, J. E. (1949). Amer. J. Path., 25, 357.

Luhan, J. A. (1946). Arch. Path., Chicago, 42, 245.

McConnell, A. A. (1952). Archives of Disease in Childhood, $27,121$.

Mouton, C. M., Smillie, J. G. and Bower, A. G. (1950). J. Pediat., 36, 482 .

Pugh, R. C. B. (1952). Gt Ormond Str. J., 2 (no. 4), p. 118.

Saphir, O. (1945). Amer. J. Path., 21, 99.

and Wile, S. A. (1942). Amer. J. med. Sci., 203, 781.

Sims-Roberts, J. T. C. and Thomson, D. (1953). Monthly Bull. Minist. Hith, Lond., August, 152 .

Smallpeice, V. and Ounsted, C.' (1952). J. Neurol., Neurosurg, Psychiat., 15, 13.

Wright, G. A. and Owen, T. K. (1952). Brit. med. J., 1, 800. 